\title{
Dunia Orang Mati Menurut Kepercayaan Masyarakat Nias
}

\author{
The World of the Dead According to Nias People's Beliefs
}

\section{Tuhoni Telaumbanua}

STT Banua Niha Keriso Protestan Sundermann tuhony@sttsundermann.ac.id

\section{ARTICLE INFO}

Submitted: May 17, 2021

Review: May 20, 2021

Accepted: June 4, 2021

Published: June 30, 2021

\section{KEYWORDS}

death, Nias, Ono Niha, spirits, world of the dead

\section{CORRESPONDENCE}

Phone:

E-mail: tuhony@sttsundermann.ac.id

\section{A B S T R A C T}

This article discusses the struggle of Nias people (Ono Niha), who are one of the oldest tribes inhabiting Nias Island, about the "world of the dead." On the one hand, Ono Niha has a high culture and a belief system that lived thousands of years from generation to generation. But on the other hand, since 1865, through the Gospel Message by RMG and NLG, Ono Niha gradually became a follower of Christ. However, despite more than 150 years of Christianity in Nias, Ono Niha struggles with the Christian faith. One of the struggles of the faith of the church's people is related to the "world of the dead." What is death? Right, do spirits enter the world community of the dead? In reality, Ono Niha, who is still faithful in carrying out his customs, still believes that the spirits of ancestors are blessings or can be angry and bring curses if his descendants do not meet the demands of the ancestors when they live. Another problem is the occurrence of possession or possessiveness experienced by the citizens of the congregation, both adults and teenagers. Here there is a conflict in Ono Niha because the church understands that all elements of the old belief are elements of disbelief and classified as occult. But on the other hand, Ono Niha still believes and lives it. To know Ono Niha's belief system about the world of the dead, this article will be presented an understanding of the human self according to Ono Niha and Ono Niha's belief in death and the world of the dead. At the end of the paper, we explain the interaction and impact of Ono Niha's old cultural and religious encounters with Christianity.

\begin{abstract}
A B S T R A K
Tulisan ini membahas tentang pergumulan masyarakat Nias (Ono Niha), yang adalah salah satu suku tertua yang mendiami kepulauan Nias, tentang "dunia orang mati". Pada satu sisi Ono Niha telah memiliki kebudayaan yang tinggi, serta system kepercayaan yang telah dihidupi ribuan tahun dari generasi ke generasi. Tetapi pada sisi lain, sejak tahun 1865, melalui Pekabaran Injil oleh RMG dan NLG, secara bertahap Ono Niha menjadi pengikut Kristus. Akan tetapi, walaupun sudah lebih 150 Tahun kekristenan di Nias, Ono Niha masih terus bergumul tentang iman kekristenan. Salah satu pergumulan iman warga jemaat adalah terkait dengan "dunia orang mati". Apakah kematian itu? Benarkan roh-roh memasuki komunitas dunia orang mati? Pada realita, Ono Niha yang masih setia dalam melaksanakan adatistiadatnya, masih banyak yang percaya bahwa roh-roh nenek moyang adalah pemberi berkat atau bisa marah dan mendatangkan kutuk bila keturunannya tidak memenuhi tuntutan nenek moyang ketika mereka hidup. Persoalan lainnya adalah terjadinya kerasukan atau kesurupan yang dialami oleh warga jemaat, baik orang dewasa dan remaja. Di sini terjadi konflik dalam diri Ono Niha, karena pihak gereja
\end{abstract}


memahami bahwa semua unsur kepercayaan lama adalah unsur kekafiran dan tergolong okultisme. Namun pada sisi lain, Ono Niha masih mempercayai dan menghayatinya. Untuk mengetahui sistem kepercayaan Ono Niha tentang dunia orang mati, dalam tulisan ini akan dikemukakan pemahaman tentang diri manusia menurut Ono Niha, serta kepercayaan Ono Niha tentang kematian dan dunia orang mati. Interaksi dan dampak dari perjumpaan kebudayaan dan agama lama Ono Niha dengan Kekristenan akan dijelaskan pada bagian akhir tulisan.

Kata kunci: arwah, dunia orang mati, kematian, Nias, Ono Niha

\section{PENDAHULUAN}

S alah satu pergumulan umat manusia di sepanjang zaman adalah menyangkut kematian. Pemahaman tentang kematian dan misteri setelah kematian berhubungan dengan sikap, tindakan dan sistem kepercayaan manusia yang masih hidup. Persoalannya ialah konflik pemahaman dan penghayatan antara kepercayaan lama dengan kepercayaan baru yang dianut. Itu yang dihadapi oleh masyarakat Nias (Ono Niha), yang dahulu memiliki agama asli dan sejak akhir abad ke-19 telah beralih menjadi penganut agama Kristen.

Masih banyak Ono Niha Kristen yang menghayati soal kematian dan dunia orang mati menurut tradisi dan pemahaman kepercayaan lama. Namun, tidak lagi dipahami bahwa pemahaman tersebut merupakan warisan sistem kepercayaan lama. Salah satu contoh mengenai pemahaman bahwa setelah tiga hari, arwah orang meninggal kembali ke rumah untuk mengambil barang-barang yang digunakannya ketika ia masih hidup, dan agar arwah orang mati tersebut tidak kembali, maka barangbarangnya (yang penting seperti tempat minuman atau tikar/kasur) ditempatkan di kuburan. Meskipun, dewasa ini jarang melakukan ritual tersebut, tetapi telah diganti dengan praktek 'menanam bunga.' Contoh lainnya adalah pemahaman bahwa arwah orang meninggal masih hidup dan bisa memberkati, sehingga alamat doa menjadi dua, yakni Tuhan di dalam Yesus Kristus, dan kepada arwah orang mati; dan untuk menjauhi kutuk, banyak Ono Niha yang berusaha keras menuruti pesannya ketika ia masih hidup.

Pemahaman lama Ono Niha tentang arwah dan dunia orang mati tentu berbenturan dengan

${ }^{1}$ Kim Ki Dong, Roh, Jiwa Dan Tubuh (Tangerang: Barea indonesia, 2003). pemahaman iman Kristen yang menekankan tidak ada hubungan orang hidup dengan yang sudah mati. Walaupun demikian, masih banyak Ono Niha Kristen yang masih menghayati dan melakukan 'hubungan' dengan arwah nenek moyang melalui doa memohon berkat kepada arwah orang mati atau memohon agar tidak mengutuk keturunannya, dan masih terdapat orang Kristen melakukan apa yang dipesan sebelum meninggal. Pergulatan iman orang Kristen adalah apakah salah menghormati orang yang telah meninggal? Apakah salah mengikuti tradisi budaya? Bagaimana sesungguhnya pemahaman Ono Niha dahulu tentang kematian dan peristiwa sesudah kematian?

Untuk menelusuri sistem kepercayaan Ono Niha tentang kematian dan peristiwa setelah kematian, maka melalui kajian literaur - tulisan ini berupaya mengkaji konsep filosofis orang Nias tentang manusia, kematian dan tentang dunia orang mati atau peristiwa setelah kematian.

\section{KONSEP FILOSOFIS ORANG NIAS TENTANG MANUSIA}

Para filsus memahami bahwa manusia terdiri dari unsur material (tubuh) dan nonmaterial (roh). ${ }^{1}$ Ada juga yang membaginya dengan tiga unsur, yakni tubuh, jiwa dan roh, dan ada yang membagi dua, yakni tubuh dan roh. Berdasarkan pemahaman tersebut, dalam tradisi Yunani, ada pemahaman bahwa tubuh adalah penjara bagi Roh, dan dipahami bahwa apabila manusia mati, tubuhnya mati tetapi rohnya berpisah dengan tubuh dan dianggap tidak mati. Bagaimana pemahaman Ono Niha tentang manusia (diri)?

Untuk mengenal pemahaman Ono Niha dahulu, Swellengrebel ${ }^{2}$ mengutip catatan

2 J. L. Swellengrebel et al., Mengikuti Jejak Leijdecker : Satu Setengah Abad Penerjemahan Alkitab Dan Penelitian 
misionaris RMG, Sundermann yang menyatakan bahwa diri manusia terdiri dari enam unsur, yakni boto, noso, eheha, tödö, mökömökö atau alölöa dödö, dan bekhu zimate. Apa maksudnya? Sundermann menjelaskannya, sebagai berikut. ${ }^{3}$

Boto (badan/sosok/pribadi). Boto dapat berarti perawakan, tempat bagi noso (napas/jiwa), tempat bagi tödö (jantung), dan daging manusia (ösi). Boto itu sendiri tidak berhayat, tetapi menjadi makhluk hidup karena noso. Ketika noso ini terputus, maka badanpun hancur. Pusat badan adalah tödö yang merupakan pusat fungsi-fungsi dan perasaan jiwa. Bila ada seseorang yang tidak arif, maka ada ungkapan "ebua mboto, ba lö sa bakha tödö." Istilah lain dari badan adalah ösi yang diterjemahkan dengan tubuh atau dalam bahasa Yunani sarx (daging).

Noso (napas/jiwa) adalah asas kehidupan manusia dan binatang. Ada pemahaman Ono Niha, bahwa noso diberikan oleh Baliu, anak dewa Lowalangi (dewa dunia atas) sejak manusia dalam kandungan. Jika seseorang banyak mendapat noso, maka ia hidup lama dan sejahtera, dan demikian sebaliknya. Sesudah kematian, noso kembali ke 'jiwa kolektif' atau kembali kepada sumber noso.

Tödö adalah hati/jantung sebagai bagian dari badan dan merupakan pusat perasaan serta akal-budi. Tödö juga memiliki arti hati nurani. Istilah tödö muncul dalam berbagai ungkapan perasaan, misalnya: ebua dödö (hati besar - kasih sayang), abu dödö (hati berambut - menyatakan perasaan duka cita), tobali dödö (hati terbalik menyatakan perasaan kaget), afönu dödö (hati penuh - untuk kemarahan), dan tobini dödö (hati tersembunyi-untuk menyatakan sikap munafik).

Eha-eha/Eheha (roh), berkaitan dengan tarikan nafas. Dalam kata kerja dapat berarti menghembusi. Eheha mengacu pada kekuatan yang menggairahkan, yang diturunkan ayah kepada anak lelakinya (tertutama di kalangan kaum bangsawan). Sehingga ada ritual fangai eheha zatua, terutama oleh anak sulung, dan ketika seseorang meninggal maka keluarga menjaga agar eheha-nya tidak dicuri oleh orang lain.

Bahasa Dalam Bahasa-Bahasa Nusantara (Jakarta: Lembaga Alkitab Indonesia, 2006).

3 Heinrich Sundermann, "Die Psychologie Des Niassen," in Allgemeine Mission Zeitschrft, ed. Johannes
Mökömökö (berkaitan dengan kata mökö yakni boto, noso, eheha, tödö, mökömökö atau alôlôa "bergerak"). Ono Niha memahamai bahwa mökömökö sebagai bagian dari tödö yang masih terus hidup setelah seseorang meninggal. Nama lain dari mökömökö adalah alölöa dödö adalah intisari dari manusia. Bila seseorang mati, intisari ini tidak mati, setelah mayat dikubur, mökömökö keluar dari kuburan. Mökömökö menjelma sebagai laba-laba, dan inilah yang disimpan dalam adu zatua. Kalau adu zatua rusak, mökömökö dapat keluar dan lari, maka $a d u$ harus dibuat dari kayu yang bagus dan dipelihara dengan baik.

Bekhu zimate (bayangan orang mati), yang kadang-kadang akan tampak beberapa saat sebelum seseorang meninggal, sebagai bayangan yang mirip dengannya. Dipahami bahwa bekhu zimate adalah roh yang tak berperawakan, yang dimiliki manusia, baik semasih hidup maupun setelah mati. Ketika seseorang mati, bekhu zimatenya berada dekat mayat, dan menginginkan barang-barang dari almarhum, bahkan menginginkan makanan seperti layaknya almarhum sewaktu hidup. Sebelum bekhu zimate mendapat tempat di dunia bawah, maka ia tinggal beberapa waktu di dekat kuburan.

Orang yang berbuat jahat, bekhu zimate-nya kembali ke kuburan dan tidak masuk ke dunia bawah. Orang yang tidak mempunyai keturunan, bekhu zimate-nya menjadi löhölöhö (kupu-kupu besar), sedangkan manusia yang bunuh diri bekhu zimate-nya tidak berkumpul bersama bekhu zimate yang lain, melainkan mempunyai tempat khusus. Apabila bumi ini lenyap dan terbentuk dunia baru maka dunia baru itu akan didiami oleh bekhubekhu orang baik, sejauh mereka mempunyai keturunan laki-laki.

Informasi lain yang diperoleh tentang diri manusia selain catatan Sundermann, antara lain: Dananjaya, memahami diri manusia terdiri dari dua unsur besar, yakni badan kasar (boto) dan badan halus (terdiri dari noso dan lumölumö). ${ }^{4}$ Faogöli Harefa menyebutkan istilah-istilah seperti boto, lumölumö atau bekhu, eheha wa'asalawia

Gustav Warneck, 14th ed. (Gütersloh: Bertelsmann, 1887), 289-302.

4 James Danandjaja, Ono Niha: Penduduk Pulau Nias, 
atau eheha, lakhömi, hati (tödö), dan mökömökö. ${ }^{5}$ Gulö mengemukakan bahwa 'roh' yang ditempatkan di patung orangtua itu bernama eheha wa'asalaŵa atau löfö. ${ }^{6}$ Filemon menyebut istilah seperti boto (akan menjadi mayat), noso (akan kembali ke 'atas'), bekhu (tinggal di kuburan), lakhômi (ditempatkan dalam patung orangtua), dan bekhu zauri (roh orang yang hidup). ${ }^{7}$ Peter Suzuki menyebutkan adanya unsur 'immortal spirit' (roh kekal) ${ }^{8}$ Afore $^{9}$ mengemukakan tödö (hati) yang mesti ditinggalkan kepada anak-anaknya. Harita juga menyebutkan istilah luluö. ${ }^{10}$

Sejumlah istilah tersebut di atas, (boto, noso, eheha, eheha wa'asalawia, bekhu, bekhu zimate, tödö, mökömökö, alölöa dödö, lakhömi, löfö, bekhu zauri, luluö), tampaknya bukanlah gambaran jumlah unsur yang membentuk diri manusia. Para penulis masing-masing menggunakan istilah yang biasa ditemukan di wilayah dan zaman dari sasaran tulisannya, walaupun istilah satu dengan lain kadang-kadang memiliki pengertian yang sama. Sebagai contoh, mengenai lakhömi. Menurut Harefa, lakhömi adalah sesuatu dari diri manusia, yang disimpan dalam patung orangtua. Kehadiran lakhömi inilah yang memungkinkan patung itu memiliki kuasa untuk memberkati. Makna seperti ini terkandung dalam istilah mökömökö (Sundermann, 1887), dan dalam eheha wa'asalawîa (Gulo, 2004). Hal yang sama dapat ditemukan dalam istilah lumölumö. Lumölumö merupakan diri kedua manusia, yang ada baik selagi hidup maupun setelah manusia mati (Danandjaja, 1976). Pemahaman yang serupa dapat ditemukan dalam istilah bekhu zimate (Sundermann), atau bekhu zauri (Filemon).

Pada mumnya, manusia dianggap terdiri dari dua unsur, yakni boto (tubuh) dan noso (jiwa). Boto adalah tubuh jasmaniah, yang dikubur bila manusia mati. Tubuh bisa dipandang berubah menjadi mökömökö bila

${ }^{5}$ Faogoli Harefa, Hikayat Dan Cerita Bangsa Serta Adat Nias (Sibolga: Rapatfonds Residentie Tapanoeli, 1939).

6 W Gulo, ed., "Injil Dan Budaya Nias," in Seminar Lokakarya Perjumpaan Injil Dan Budaya Nias Di Gunungsitoli Nias (Gunungsitoli: Panitia Semiloka, 2004), 205.

7 Toeria, April, 1916, hal. 14-15.

8 Peter Suzuki, The Religious System and Culture of Nias, Indonesia (Washington: 'S Gravenhage., 1959).

9 Toeria, Maret 1915, hal.11-12. seseorang meninggal atau lenyap saja. Kenyataan itu tidak mempengaruhi jumlah unsur dalam diri manusia. Noso adalah unsur rohaniah, merupakan prinsip yang menghidupi tubuh (bnd. Sundermann). Unsur ini hanya dapat dilihat oleh Ere (imam). ${ }^{11}$ Noso memiliki aspek rohaniah, yang disebut lumölumö (bnd. Dananjaya, Harefa, Thomas), atau bekhu zauri (bnd. Filemon), atau bekhu zimate (bnd. Sundermann), atau eheha (bnd. Sundermann, Hadiwijono), atau eheha wa'asalawia (roh kemuliaan, bnd. Harefa), lakhômi (bnd. Filemon, Harefa, Hadiwijono), atau tödö (bnd. Afore, Harefa), atau mökömökö (bnd. Sundermann), atau alölöa dödö (bnd. Sundermann), atau luluö (bnd. Harita), yang mesti diwarisi kepada anak-anak. Pewarisan dapat dilakukan dengan cara memindahkan aspek rohaniah itu langsung kepada si anak, atau dengan menempatkannya dalam patung orangtua (adu zatua). Pewarisan itu tampaknya merupakan simbolisasi kehadiran dan keterhubungan yang kontinyu antara kuasa orangtua dengan keluarga dan keturunannya.

Aspek rohaniah dipahami sebagai kualitas atau potensi yang luar biasa dari noso, yang memberi semangat, kebijaksanaan dan kemampuan kepada manusia. Namun, aspek ini tidak otomatis kentara dalam setiap manusia. Ia lebih bersifat kemungkinan (possibility), yang memerlukan kondisi yang kondusif untuk dapat mewujud. Pada kenyataannya, aspek rohaniah ini hanya dibicarakan berkaitan dengan bangsawan. ${ }^{1213}$ Sekilas hal ini seolah-olah mengatakan bahwa aspek rohaniah hanyalah milik bangsawan dan orang kaya. Namun, di sisi lain jalan untuk menjadi bangsawan dapat ditempuh oleh siapapun yang dapat melakukan pesta-pesta besar (owasa), ${ }^{14}$ tanpa ditentukan oleh garis keturunan, melainkan harta. Jelas, bahwa setiap orang mempunyai kemungkinan untuk menjadi bangsawan. Dengan demikian, kemungkinan menjadi bangsawan itu pula

10 Sarofanotona Harita, “Gerakan Pertobatan Masal Sebagai Hasil Pertemuan Gerakan Pietisme Dengan Nilai-Nilai Budaya Agama Suku Nias" (Tesis, Sekolah Tinggi Teologi Jakarta, 1990), 35.

11 Harita, “Gerakan Pertobatan Masal Sebagai Hasil Pertemuan Gerakan Pietisme Dengan Nilai-Nilai Budaya Agama Suku Nias."

12 Bnd. Harun. Hadiwijono, Religi Suku Murba Di Indonesia (BPK Gunung Mulia, 2000), 93.

${ }^{13}$ Bnd. Harefa, Hikayat Dan Cerita Bangsa Serta Adat Nias

14 Ibid. 
menjadi kemungkinan untuk memiliki aspek rohaniah. Aspek rohaniah itu dapat diasah oleh harta dan upacara-upacara adat, yang dapat meningkatkan status sosial seseorang hingga mencapai derajat bangsawan yang tertinggi, yakni balugu atau si'ulu, atau salâ̂a. Aspek ini akan kembali ke tempat berasalnya noso, yakni Teteholi Ana'a. (bnd. Sundermann, Dananjaya) dengan menyeberangi bawa gawuwukha (mulut samudra).

Selain aspek rohaniah, noso manusia memiliki aspek 'setaniah' (mengandung setan). Aspek ini merupakan kekuatan, yang dalam keadaan-keadaan tertentu, dapat mengganggu ketentraman manusia, dan menakutkan. Keadaan-keadaan dimaksud antara lain bila kematian seseorang tidak diupacarai, bila patung orangtua sudah rusak, bila seseorang mati bunuh diri, atau dibunuh, bila seseorang telah berbuat jahat, bila mati di saat melahirkan (noso-nya menjadi roh jahat, yang disebut matiana), bila mati di sungai, dll. Kekuatan itu, bila seseorang meninggal, menetap di kuburan (bnd. Filemon) atau menuju tempat tertentu, dan tidak dapat bergabung dengan kekuatan aspek rohaniah.

Versi lain dapat dikemukakan terhadap konsep dua unsur ini. Noso, pada waktu seseorang meninggal tidak mati, melainkan menuju tempat yang layak baginya. Orang baik, yang mempunyai keturunan, yang telah melakukan owasa, dan kematiannya diupacarai, noso-nya menuju Teteholi Ana'a. Tetapi sebaliknya, mereka yang jahat dan belum melakukan owasa, nosonya menuju dunia bawah. Namun, orang baik masih dibutuhkan oleh keluarga. Oleh karena itu, sebagai simbol kehadiran dan keterhubungan almarhum dengan keluarganya, dibuatkan patung, yang diisi dengan noso orangtua, dengan sebutan eheha atau eheha wa'asalâ̂́a atau mökömökö, atau luluô atau alölöa dödö atau tödö, atau lakhömi, dan kemudian dinamai patung orangtua (adu zatua). Semua ini dilakukan melalui acara ritual dengan menjalani sejumlah ritus dan pesta.

Selain pemahaman dua unsur di atas, manusia dapat dipandang terdiri dari tiga unsur, yakni boto, noso, dan lumôlumô. Boto merupakan tubuh jasmaniah, tempat bagi noso dan lumölumö. Noso adalah prinsip yang menghidupi tubuh, yang akan kembali ke asalnya bila seseorang meninggal. Lumôlumô atau bekhu zauri atau bekhu zimate, merupakan diri kedua manusia (bnd. Dananjaya, Filemon, Sundermann), dalam eksistensi rohaniah, yang ada baik sewaktu masih hidup maupun setelah mati. Bila seseorang mati, lumölumö-nya tidak mati, tetapi berubah nama menjadi bekhu. ${ }^{15}$ Lumölumö atau bekhu itu memiliki aspek rohaniah, yang disebut eheha, atau eheha wa'asalâ̂ंa atau lakhömi atau mökömökö atau luluö atau alölöa dödö atau tödö. Aspek ini dapat diwariskan kepada anak-anak dan ditempatkan pada adu zatua. Bekhu (minus aspek rohaniah) selanjutnya menetap di kuburan, dan kadang-kadang mengganggu dan menakutkan.

Dua konsep di atas dapat berkembang menjadi konsep baru, bila hal-hal yang merupakan aspek dianggap sebagai unsur. Bila gagasan itu dikembangkan, maka konsep dua unsur maunpun tiga unsur dapat pula dipandang sebagai konsep empat unsur, dimana aspek rohaniah dan aspek setaniah dianggap sebagai unsur-unsur yang terdapat dalam eksistensi noso (konsep dua unsur), atau aspek rohaniah menjadi salah satu unsur dalam eksistensi lumölumö (konsep tiga unsur). Jadi, konsep empat unsur memberi dua versi kemungkinan. Versi pertama, manusia terdiri dari boto, noso, unsur rohaniah (lumölumö, atau bekhu zauri, atau bekhu zimate, atau eheha, atau eheha wa'asalawâ, atau lakhömi, atau tödö, atau mökömökö, atau alölöa dödö, atau luluö), dan unsur setaniah (bekhu). Sedangkan versi kedua, manusia terdiri dari boto, noso, lumölömö, dan unsur rohaniah (eheha, atau eheha wa'asala $\hat{w} a$ atau lakhömi atau mökömökö atau luluö atau alölöa dödö atau tödö).

Dari berbagai kemungkinan di atas (dua unsur, tiga unsur atau empat unsur), tampak bahwa masyarakat Nias memahami adanya kekekalan manusia. Semua sumber yang penulis gunakan mengisyaratkan bahwa unsur rohaniah manusia (seperti noso, atau lumölumö, dll) bersifat kekal.

Sedangkan unsur jasmaniah (boto) akan berakhir pada kematian. Dengan demikian, yang terpenting dalam diri manusia adalah unsurunsur rohaniah itu: noso, atau lumölumö, atau keduanya. Atau rumusan yang lebih tepat ialah bahwa diri (self) manusia adalah unsur-unsur

${ }^{15}$ Danandjaja, Ono Niha: Penduduk Pulau Nias. 
rohaniahnya, yakni noso, atau lumölumö, atau keduanya. Tubuh merupakan tempat sementara bagi unsur-unsur itu di bumi ini, sarana kelahiran dan kehadiran di bumi. Tetapi, setelah meninggal, tanpa tubuh, manusia dianggap tetap hadir, dalam patung atau dalam diri si anak. Sekalipun seseorang telah mati, namun dia tetap hidup dalam kehidupan keluarganya. Noso atau lumölumö seseorang cukup dianggap penting. Anak-anak dari seorang ayah yang meninggal, berusaha melakukan acara-acara setelah kematian, untuk membantu memperlancar perjalanan 'pulang' jiwa sang ayah ke tujuan akhir. Kewajiban sang anak untuk mematuhi pesan-pesan sang ayah almarhum menjelang mati, selain memberi keuntungan bagi diri si anak, juga bagi si almarhum.

Apabila diperhadapkan dalam kehidupan keseharian dan sistem kepercayaan Ono Niha, maka tampak ada dua dunia bagi Ono Niha, yakni banua (kehidupan di dunia sekarang ini semasih hidup), dan kehidupan sekaitan dengan sesudah kematian (banua tou/furi). Bahwa benar ada beberapa unsur psikologi dan unsur yang muncul sewaktu hidup (boto, tödö, noso, eheha); dan ada unsur atau elemen yang muncul pada waktu kematian dan sesudahnya, seperti Mökömökö, Eheha, dan Bekhu Zimate. Bagaimana unsur ini dalam kaitan dengan kematian dan sesudah kematian?

\section{Kematian menurut Ono Niha}

Masyarakat Nias menyebut kematian dengan berbagai istilah, antara lain: aetu noso (putus nyawa), mondröi ulidanö (meninggal dunia), mofanö (pergi), ahuwa (suatu keadaan menuju akhir), alele (tidak berdaya sama sekali), dll. Kematian adalah nasib seseorang. Semua orang mengalami mati, baik orang tua maupun anak-anak, dan itu tidak dapat dihalangi. ${ }^{16}$ Kalau kematian harus terjadi, itu berarti seseorang telah mencapai batas permintaannya (no irugi angandröwiania). ${ }^{1718}$ Noso yang dia minta sewaktu di kandungan sudah mencapai batas. Itulah nasibnya. Oleh karena itu kematian tidak perlu dihindari. Dalam Hoho ba zimate yang ditulis oleh

16 Gumaô, "Hoho...," Relienbook, 196.

17 Sundermann, "Die Psychologie Des Niassen."

18 Menurut Sundermann noso manusia paling berat 10 gram. Berat ringannya noso menentukan panjang pendeknya umur seseorang.
Guru Zemo Gumao dalam Realienboek, dan Hoho ba zimate yang ditulis oleh Thomsen, dan ditulis serta ditafsirkan ulang oleh P. Johannes, M. Hammerle, OFMCap ${ }^{19}$ menyatakan bahwa hidup di dunia ini tidak selamanya, dan tidak ada jalan keluar untuk lepas dari kematian. Beberapa syair berikut.

Hendre mena zi lö amatela niha, hendre mena zi lö asao zato.

Iwaö Siwaria, lakha zihönö, iwaö Siwaria, lakha zato: Lö sa khögu hilu lala gamatela, lö sa khögu hilu gaetula noso. Oi wö lala hö niha ba gulidanö, oi wö lala hö niha ba guli ndrao. Fangesolo gulö'ulö, fangatabö deteho.

Hendre zi lö amatela niha, hendre zi lö asao zato?

Iwaö amania börö zatua, iwaö ama börö zeroro: Lö sa hilu lala gamatela, lö sa hilu gaetula noso. Oi lala hö niha ba danö, oi lala hö niha ba ndrao. Oi lala gamatela zumbila, oi lala gamatela moyo.

Dengan kesadaran bahwa tidak ada jalan menghindari kematian, maka manusia Nias malah mempersiapkan diri menyambut kematian. Salah satu makna acara fangotome'ö atau famalakhisi adalah dalam rangka persiapan itu. Yang dihindari oleh Ono Niha adalah penyakit, yang diyakini disebabkan oleh kemarahan arwah leluhur atau makhlukmakhluk halus serta Lature Danö. Untuk itu masyarakat Nias terus berusaha menghidarkan diri dari semua oknum tersebut dengan cara menaati adat sesuai hukum-hukumnya, melakukan ritus pembuatan patung dan pemberian sesaji, yang dipimpin oleh Ere. Kematian itu bisa terjadi dengan berbagai cara: karena dibunuh atau bunuh diri, kecelakaan, penyakit, dan usia lanjut. Selain itu masyarakat Nias juga memahami bahwa kematian disebabkan oleh karena makhluk-makhluk halus telah memakan 'bayangan' seseorang, 2021 termasuk dewa dunia bawah (Lature Danö).

\section{Apa yang terjadi setelah kematian?}

Penjelasan terhadap diri manusia pada bagian kedua di atas, memberi gambaran bagi kita, bahwa dalam pandangan masyarakat Nias, manusia memiliki sesuatu yang kekal, yakni unsur rohaniahnya, noso atau lumölumö atau

19 Johannes M. Hämmerle, Lawaendröna - Si Pencari Kehidupan Abadi Hingga Ke Bulan (Gunungsitoli: Museum Pusaka Nias, 2013).

${ }^{20}$ Harefa, Hikayat Dan Cerita Bangsa Serta Adat Nias.

${ }^{21}$ Bnd. Suzuki, The Religious System and Culture of Nias, Indonesia. 
keduanya. Unsur itu pada hakikatnya mesti kembali kepada asalnya,22 atau ke dunia roh nenek moyangnya. ${ }^{23}$ Aktifitas di sekitar kematian tampak memperlihatkan gagasan itu. Perjamuan terakhir bagi orangtua yang hendak meninggal mengandung makna sebagai persiapan untuk bertemu dengan para leluhur. ${ }^{24}$ Dalam kegiatan-kegiatan sekitar kematian, simbol-simbol dunia atas dan dunia bawah digunakan. ${ }^{25}$ Simbol-simbol dunia atas antara lain: kain sutera, emas, kumpulan patung leluhur, warna kuning, warna keemasan, burung elang, payung berwarna keemasan, matahari, ayam, lauru, hulu, timur, dll. Simbol dunia bawah antara lain: ular, buaya, warna merah, warna gelap, bulan, hilir, barat, dll. Penempatan adu zatua yang baru di deretan nadu sebelumnya (atia nadu) merupakan simbol dari berkumpulnya kembali orang meninggal dengan para leluhur.

Tapi kembali ke asal tidak bersifat otomatis. Mencapai itu sangat ditentukan oleh sejauh mana dia telah melaksanakan adat sewaktu di bumi. Apabila di bumi, seseorang telah melaksanakan ketentuan-ketentuan adat, dan mencapai status sosial yang tinggi (si'ulu atau balugu), maka dia telah memenuhi sistem kehidupan dunia atas, dan akan kembali ke dunia atas itu. ${ }^{2627}$ Upaya-upaya itu dilakukan tidak hanya oleh seseorang untuk kepentingan dirinya sendiri, tetapi juga oleh anak-anaknya, untuk kepentingan orangtuanya. ${ }^{28}$ Oleh karena itu kehadiran anak sangat diharapkan oleh keluarga-keluarga Nias. Namun, kalau di bumi hanya dapat menjadi manusia kebanyakan saja, maka dia menetap di dunia bawah. Ada pertimbangan-pertimbangan etis, namun hukuman (ogautö) atas kesalahan-kesalahan etis itu masih dapat ditebus selama di dunia melalui hukum-hukum adat. ${ }^{29}$ Pelanggaran etis sesungguhnya adalah pelanggaran terhadap hukum adat itu sendiri. Jadi, kembali ke Teteholi

22 Sundermann, "Die Psychologie Des Niassen."

23 J.W. Thomas, Berichte der Rheinische MissionsGesellschaft (n.d.): 13-15.

24 Toeria, Ombôlata, Juli-Agustus 1924, hal.25-26.

25 Suzuki, The Religious System and Culture of Nias, Indonesia

26 Gulo, "Injil Dan Budaya Nias."

27 Harefa, Hikayat Dan Cerita Bangsa Serta Adat Nias.

28 Danandjaja, Ono Niha: Penduduk Pulau Nias.

${ }^{29}$ Harefa, Hikayat Dan Cerita Bangsa Serta Adat Nias.

30 Ibid.
Ana'a hanyalah mungkin terjadi melalui adat (lala hada).

Hal tersebut tampak sejalan dengan pemahaman orang Nias terhadap mitos-mitos asal-usul mereka, yang dianggap berasal dari dunia atas, dan ketika diturunkan ke bumi, kepada mereka diikutkan segala peraturan hukum adat. ${ }^{30}$ Mitos-mitos tersebut hendak mengungkapkan bahwa manusia yang diturunkan dari Teteholi Ana'a itu akan hidup di bumi berdasarkan sistem dunia atas. Dengan demikian tugas utama manusia di bumi adalah memelihara dan menjalankan sistem kehidupan dunia atas dimaksud. Hanya dalam sistem itulah Ono Niha dapat memelihara hubungan yang harmonis dengan leluhurnya dan para dewa. Hubungan itu merupakan jaminan kesejahteraan, jaminan bagi hidup yang terberkati di bumi. Oleh karena itu orang selalu berusaha menyelenggarakan adat. ${ }^{31}$ Sistem dunia atas merupakan sistem hidup ideal. Jadi, manusia datang (diturunkan) dengan membawa adat, maka akan pulang melalui adat juga. Dalam hal ini mati berarti kesempatan untuk kembali ${ }^{32}$ ke dalam kehidupan leluhur.

Dalam kerangka berpikir ini dapat dipahami mengapa orang yang tidak mempunyai keturunan, ${ }^{33}$ orang yang melanggar norma-norma etis, ${ }^{34}$ orang miskin, ${ }^{35}$ tidak memiliki kesempatan kembali ke dunia atas. Ketiadaan keturunan menyebabkan seseorang hanya dapat mencapai derajat tertentu, dan tidak ada anaknya yang akan mengupacarakan kematiannya. Orang miskin, jelas tidak akan dapat menyelenggarakan serangkaian adat, karena pada kenyataannya penyelenggaraan adat membutuhkan harta benda. Orang-orang yang melanggar hukum etis, sekaligus menjadi orang-orang yang melanggar hukum adat itu sendiri.

Kembali ke asal berarti meninggalkan bumi ini. Beberapa istilah yang digunakan bagi

31 Lödomboea, “Owasa,” 168.

32 Bnd. Suzuki, The Religious System and Culture of Nias, Indonesia.

33 Orang yang tidak mempunyai keturunan akan menjadi kupu-kupu besar (löhöôlöhö), lihat Guru Fetero, "Lewatô,"149; Sundermann, "Die Psychologie Des Niassen."

34 Bagi mereka yang mati bunuh diri, atau pernah membunuh, disediakan tempat khusus, Ibid.

35 S. Zebua, Sejarah Kebudayaan Ono Niha, Seri 2. n.d., 396. 
kematian juga mengandung makna demikian, seperti mondröi ulidanö (meninggalkan bumi), mofanö (pergi), dll. Masyarakat Nias meyakini bahwa seseorang yang mati, menyadari kepergiannya meninggalkan bumi ini. Kesadaran itu terjadi pada hari keempat setelah dikubur. Kesadaran almarhum itu ternyata mengandung makna bagi keluarga, dan oleh karena itu sesuatu hal dilakukan, yakni pembuatan patung orangtua (adu zatua) dan pemisahan arwah dari keluarga (fanibo tufo atau fobale lewatö).

Hal ini menunjukkan, bahwa masyarakat Nias merasa wajib untuk terus memelihara hubungan dengan almarhum (melalui adu zatua), sekalipun mereka menyadari, bahwa dunia dan hakikat di antara mereka berbeda. Melalui fanibo tufo keluarga hendak menyatakan kepada orang mati bahwa hakikat dan tempatnya kini berbeda. Kematian memisahkan tempat dan hakikat antara orang mati dengan orang hidup, tetapi hubungan di antara keduanya berjalan seperti biasa. Orangtua yang meninggal tetap orangtua bagi anak-anaknya, yang selalu dikenang dan dihormati dalam seluruh aktivitas hidupnya, terutama ketika si anak menyelenggarakan adatistiadat. Dengan demikian, kembali ke asal, tetap tidak memutuskan hubungan dengan keluarga yang masih hidup.

Di mana asal yang mau dicapai itu? Istilah yang muncul sehubungan dengan itu cukup bervariasi. ${ }^{36}$ Tapi dari semuanya dapat dipastikan, bahwa yang dimaksud adalah 'dunia atas' di mana dewa Lowalangi berada. Terminologi Lowalangi sebagai nama Allah dalam konteks Nias dapat dibaca lebih lanjut pada artikel Sonny Zalukhu (Lowalangi: From the name of an ethnic religious figure to the name of God). ${ }^{37}$ Kembali ke asal itu berarti kembali ke dunia Teteholi Ana'a. Dunia ini dianggap kekal. Dunia itu bahkan menjadi pengganti dari bumi ini, yang akan 'tenggelam' bila akhirat tiba. Namun, sebagaimana telah dijelaskan di atas, bahwa yang dapat memasukinya kembali hanyalah mereka-mereka yang telah memelihara dan melaksanakan di bumi sistem hidup Teteholi $A n a^{\prime} a$, maka orang-orang yang tidak mempunyai kesempatan untuk itu menuju tempat lain. Istilah

36 Sundermann, "Die Psychologie Des Niassen."

${ }^{37}$ Sonny E. Zaluchu, "Lowalangi: From the Name of an Ethnic Religious Figure to the Name of God," HTS Teologiese Studies / Theological Studies 77, no. 4 (April untuk tempat ini juga cukup variatif. Sundermann (1887) mengatakan mereka tinggal di kuburan atau tempat khusus, yang mana menurut Harefa (1939), kuburan (sinela) merupakan kampungnya setan; tapi dapat dikatakan, bahwa tempat bagi mereka yang tidak beruntung itu adalah di tempat Lature Danö, di dunia bawah. ${ }^{38}$ Lature Danô merupakan penguasa kematian dan dewa bagi orang-orang mati.

Pernyataan di atas tampaknya mengulang kisah kemenangan Lowalangi dan kegagalan Lature Danö. Manusia analog dengan dewa-dewa itu. Manusia yang berhasil melaksanakan adat turut mewarisi Teteholi Ana'a, tetapi yang gagal masuk ke dunia bawah. Kenyataan ini juga sebenarnya sesuai dengan pepatah Nias, yang sampai sekarang masih sering dikemukakan: zilatao manu, mangawuli ba halama zoyo bu (yang berambut merah kembali ke tempat yang tidak beradat). Zilatao manu, dari kata silatao manu, artinya ayam jantan, dan ini merupakan simbol dari Lowalangi atau dunia atas; sedangkan zoyo, dari kata soyo, artinya merah, dan warna ini merupakan lambang dari dunia bawah. Hal itu sekaligus menyatakan, bahwa hidup manusia adalah kesempatan untuk memperoleh kualitas hidup seperti kualitas hidup Lowalangi.

Persoalan lain yang lebih rumit adalah mengenai saat di mana seseorang dinyatakan kembali ke Teteholi Ana'a atau ke dunia bawah. Tidak ada satu pernyataan pun yang penulis temukan dari sumber-sumber yang digunakan. Namun, dari berbagai pendapat yang ada, Misalnya, menurut Fetero dalam dalam Realienboek... (1923:149) meyakini adanya penghakiman setelah kematian. Dapat dikatakan ialah bahwa setelah mati, seseorang berada di kuburan hingga saat penghakiman datang. Oleh karena itu kuburan juga dinamai dela (arti hurufiah: titian), merupakan titian (perhentian sementara) menuju tempat akhir. Barangkali pemahaman ini pulalah yang mendasari sikap masyarakat Nias pada umumnya, hingga sekarang, yang cukup memperhatikan kuburankuburan para orangtua, membersihkannya dan membuatnya mulia, bahkan datang untuk

20, 2021), http://www.hts.org.za/index. php/HTS/article/view/6390.

38 E.E.W.G. Schröder, Nias: Ethnographische (N. v. bockhandel en drukkerij voorheen E. J. Brill, 1917), 476. 
bertanya tentang kesulitan-kesulitan hidup yang dihadapi, sembari membawa sesaji.

\section{Hubungan Manusia dengan Dewa-dewa}

Masih terus hidup sampai sekarang pemahaman bahwa Ono Niha berasal dari dunia atas, bernama Teteholi Ana'a. Sebelum kekristenan datang ke Nias, Ono Niha memahami bahwa mereka adalah ciptaan para dewa. Para dewa adalah leluhur mereka. Dewa-dewa pemilik manusia, yang diistilahkan sebagai "Babi para dewa" (bawi Lowalangi dan Lature Danö). Oleh karena itu, pola kehidupan dan tingkah laku manusia di bumi harus mencerminkan kehidupan di Teteholi Ana'a, demi keharmonisan kosmos.

Dalam mite dijelaskan bahwa ketika leluhur Nias diturunkan dari Teteholi Ana'a, diikutsertakan kepada mereka segala yang dibutuhkan, yakni rumah lengkap dengan peralatannya, semua alat ukur atau timbangan (Afore = alat ukur babi, Lauru = alat timbangan padi/beras, Fali'era = alat timbang emas); semua jenis tanaman, binatang-binatang, termasuk pinang, gambir dan sirih. Demikian juga segenap perhiasan, termasuk bait (osali) serta berbagai macam $A d u$ (patung).

Mite tersebut hendak mengungkapkan bahwa manusia yang diturunkan dari Teteholi Ana'a itu telah mempersiapkan segenap kebutuhan, termasuk sistem hukum adat dan religinya. Hal ini penting untuk menjaga hubungan dengan allah atau leluhurnya, sehingga manusia yang ada di bumi ini tetap hidup dalam kesejahteraan. Dalam hal ini Lowalangi adalah sumber kehidupan, kesejahteraan dan berkat. Untuk itu, manusia memelihara hubungan harmonis dengan allahnya, melalui penghormatan atau penyembahan dan ketaatan pada sang khaliknya. Hal ini diwujudkan melalui kewajiban menaati hukum adat dan ritus-ritus keagamaan dalam segenap kehidupan Ono Niha.

Ketaatan dan penyembahan kepada dewadewa yang baik adalah juga untuk maksud mohon perlindungan karena adanya ancaman dari roh-roh jahat yang mau menyerang dan

39 Bamböwö Laiya, Solidaritas Kekeluargaan Dalam Salah Satu Masyarakat Desa Di Nias, Indonesia (Yogyakarta: Gadjah Mada University Press, 1980). mempersulit manusia. Ono Niha mengenal beberapa dewa rendah (roh halus) yang disebut "bekhu", yakni: Bekhu Gatua (hantu hutan), Bekhu Dalu Mbanua (Roh yang bergentayangan di langit); Zihi (hantu laut), Simalapari (hantu sungai), Bela (hantu yang berdiam di atas pohon, pemilik semua binatang di hutan), Matiana, roh wanita yang mati ketika melahirkan bayi, lalu roh ini menjadi pengganggu para wanita yang mau melahirkan; Salöfö, yakni roh orang yang pandai berburu, dan berbagai roh jahat yang tinggal di gua, yang tinggal pohon besar, sungai dan muara sungai. 39

Semua roh-roh tersebut ditakuti oleh Ono Niha dan mereka berusaha menghindarinya dengan menaati tabu (famoni) atau menenangkannya melalui ritus-ritus penyembahan. Berdasarkan itulah misionaris Wagner dengan pandangan yang sedikit negatif menyimpulkan bahwa poros agama asli Nias adalah ketakutan. ${ }^{40}$ Segala sesuatu yang dilakukan oleh masyarakat Nias dalam kehidupannya tidak jauh dari hal-hal yang berkaitan dengan kepercayaan mereka. Apa yang mereka percayai, turut mempengaruhi tindakan mereka, sehingga ketika melakukan sesuatupun mereka harus melihat hari baik, dan agar mereka terhindar dari segala macam pernyakit yang diakibatkan oleh roh jahat, mereka memakai jimat-jimat agar kebal. Ada hari-hari mujur dan hari-hari tidak mujur untuk membangun rumah, untuk menanam padi, untuk perkawinan, dan selanjutnya. Ada jimatjimat yang membuat kekebalan sehingga tidak dapat melukai, dan lain-lain.

Semua ini merupakan upaya mengindari ancaman roh-roh tersebut. Lebih dari itu, untuk menjaga keserasian hidup dan kelangsungan hidup alam semesta, masyarakat Nias harus memberikan persembahan-persembahan kepada dewa-dewa. ${ }^{41}$ Di sinilah Ere (imam) berfungsi melaksanakan ritus-ritus memberi persembahan melalui $A d u$ sebagai media. Pada sisi lain, upaya menyenangkan hati dewa dan roh-roh tersebut diwujudkan dalam ketaatan terhadap adatistiadat. Untuk mendalami bagian tersebut, berikut ini akan diuraikan tentang Adu (ritus keagamaan) dan tertib sosial melalui hukum adatistiadat.

40 Richard Wagner, Die Mission Auf Nias (Barmen: Missionshaus, 1915), 31.

41 Heinrich Sundermann, Die Insel Nias Und Die Mission Daselbst: (Mit Anhang, "Niassische Literatur") : Eine Monographie (Barmen: Verlag des Missionhauses, 1905). 
Bila kelahiran dianggap sebagai datangnya kehidupan baru, perkawinan dipahami sebagai upaya mencari sumber kehidupan, maka kematian dianggap sebagai muara kehidupan. Istilah lain yang sering digunakan adalah "putus nyawa" (aetu noso). Tubuh menjadi debu dan noso kembali kepada pemberi, yakni Lowalangi. Pada mite lain disebut pemilik dan pemberi noso adalah Baliu, anak Lowalangi. Panjang pendeknya umur seseorang tergantung berat dan ringannya noso yang diperoleh semasih dalam kandungan. Bila manusia meninggal dunia, ia tak boleh menyesal, karena itu sudah permintaannya sejak dalam kandungan. Hal tersebut terlihat dari ungkapan: "telah mencapai batas permohonannya" (No irugi fangandrönia). ${ }^{42}$

Selain noso (nyawa) yang kembali ke Baliu, Ono Niha juga mengenal yang disebut dengan Bekhu zimate (roh atau makhluk halus). ${ }^{43}$ Semasih manusia hidup, bekhu zimate ini berbentuk bayangan (lumölumö) khusus. Bila mati, bekhu zimate masih dekat mayat. Ia tak mau pisah karena banyak barang-barang yang ia sukai. Itulah sebabnya Ono Niha membawa barangbarang yang bersangkutan di kuburan. Bahkan masih memberi makan empat hari lagi setelah mati agar bekhunya makan. Bila ayam berkotek, maka Ono Niha menyatakan bahwa ayam-ayam tersebut melihat bekhu zimate. Setelah empat hari, bekhu zimate turun ke "banua niha tou," tak tahu dimana. Tetapi diidentikan dengan kuburan. Ini kota kematian. Di sini bekhu mati sekali lagi, bahkan kematiannya sebanyak umurnya, dan paling tidak sembilan kali. Di kota kematian bekhu-bekhu hidup sama seperti di dunia. Hal tersebut didasarkan pada mimpi, dimana kalau mimpi terlihat orang-orang yang telah meninggal, ada banua, ada barang-barang, dan sebagainya. Status bekhu di dunia bawah sama seperti statusnya ketika ia hidup di dunia ini. Orang yang melakukan kejahatan pada waktu hidupnya, bekhunya akan kembali ke dalam kuburan, ditimpa tanah, sehingga bekhu ini sering mengutuk dengan ungkapan "biarlah engkau ditimbun oleh tanah" (yamulangögö ia tanö).

Dipercayai juga bahwa bila orang mati, ada penghakiman. Mereka harus menjawab apa yang pernah mereka buat ketika di dunia. Yang menghakimi atau menuntut mereka adalah tanah atau bumi itu sendiri. Yang meninggal dunia tanpa keturunan mereka dijadikan löhölöhö. Bila löhölöhö dibunuh, maka akan menjadi lawere. Sedangkan yang bunuh diri dan yang membunuh tak bisa bersama bekhu lain, tetapi punya tempat khusus. ${ }^{4}$

Ono Niha juga memahami soal "akhirat" (atua danö), yakni bumi ini tenggelam dalam laut. Lalu ada bumi yang baru yakni tingkat kesembilan (teratas) akan turun. Di sini roh kucing akan bantu bekhu zimate dari manusia yang menyeberangi jembatan yang disebut "mulut samudra" (bawa gawuwukha). Jembatan itu seperti pedang yang tajam. Bila di dunia kucing dibunuh tanpa alasan, maka bekhu orang tersebut akan dijatuhkan ke bawah oleh Mao. Itulah sebabnya Ono Niha takut mendekati kucing. Hanya orang baik dan dari kaum bangsawan yang masuk dunia orang mati, sedangkan yang jahat masuk kuburan. Yang punya keturunan laki-laki yang bisa menyeberangi bawa gawuwukha, bila tidak maka akan menjadi kupukupu (löhölöhö). Bekhu anakanak dapat ikut bila digendong oleh ibunya. ibunya. ${ }^{4}$

\section{Sikap Kekristenan terhadap Kematian dan Dunia Orang Mati}

Ketika para misiaonaris RMG dan NLG tiba di Nias untuk memberitakan Injil, mereka berhadapan dengan upacara-upacara di seputar kematian dan mereka memahaminya sebagai bahagian dari 'kegelapan kafir'. ${ }^{46}$ Walaupun mereka bertekad memerangi kegelapan ini, di awal pekerjaan zending, mereka lebih toleran dan hanya berusaha memisahkan unsur agama $(a d u)$ dari upacara-upacara adat. Kematian orang Kristen pertama dari Hilina'a, Balugu Jawaduha, merupakan contoh yang menarik. ${ }^{47}$ Misionaris Denninger dan Kramer memberi ijin bagi keluarga untuk melakukan upacara adat (Sitte) bagi Jawaduha, kecuali pembuatan adu. Dengan ijin ini, keluarga dari Jawaduha dapat melakukan ritus-ritus seperti fangotome'ö ${ }^{48}$, fanema lakhömi, fogo'o dan fangasi. Satu-satunya upacara yang
42 Sundermann, “Die Psychologie Des Niassen."
43 Ibid.
44 Gr Fetero, "Lewato," dalam Realienboek... 1923, 149.

\footnotetext{
45 Sundermann, "Die Psychologie Des Niassen."

46 BRM, 1870, hal. 35.

47 BRM, 1875, hal. 311-315.

48 BRM, 1875, hal. 312.
} 
tidak diijinkan adalah fangai mökömökö, yaitu pembuatan dan penyembahan adu zatua.

Penerimaan terhadap ritus-ritus lain itu sama sekali tidak berarti para misionaris menyetujui sepenuhnya semua unsur adat, tapi melalui pendekatan ini mereka berusaha memenangkan hati Ono Niha yang belum menjadi Kristen dan berusaha membuat mereka terbuka dan tertarik pada Injil. Kramer berpendapat bahwa upaya zending untuk memaksa Ono Niha mengikuti 'tradisi-tradisi lain' tidaklah tepat. Dia berpikir, adalah penting bagi para misionaris untuk menyucikan tradisitradisi adat ini melalui Firman Allah dan doa. ${ }^{49}$ Upaya untuk menyucikan adat dan tradisi ini dipraktekkan dalam pemakaman Jawaduha.

Di samping pelarangan pembuatan dan penyembahan $a d u$, para misionaris juga menggantikan ritus pemakaman tradisional dengan ibadah pemakaman Kristiani. Melalui ini, peran ere diambil alih oleh misionaris. Ada ceritera bahwa untk ibadah pemakaman itu, para misionaris mengumpulkan semua orang Kristen mengelilingi jenazah bersama keluarga almarhum. Lalu Kraemer memimpin liturgi dan Denninger berkhotbah. Sesudah itu peti di bawa keluar dan di depan pintu, sebuah mahkota berwarna emas ditempatkan di atas peti. Kemudian dibawa ke tempat pemakaman di halaman rumah Jawaduha. Sesudah pemakaman misionaris menempatkan sebuah salib di atas makam, seprti layaknya kebiasaan di Jerman. Dengan jalan mengambil alih fungsi ere, para misionaris berharap bahwa mereka telah mencegah orang melakukan pemujaan terhadap arwah almarhum.

Karena para misionaris mengijinkan orangorang Kristen pertama di Nias untuk menjalankan upacara adat bagi orang meninggal, Ono Niha berpikir Kekristenan tidak merusakkan kebudayaan dan tradisi mereka kecuali adu. Namun dari ceritera tentang pemakaman Jawaduha orang dapat melihat bahwa fungsi $a d u$ tidak sepenuhnya menghilang, tapi bergeser pada bentuk yang lain. Sebelum Kekristenan, orang tua adalah pelindung dan sumber berkat (sangehowu); bila mereka meninggal, mereka tetap hadir melalui $a d u$. Sekarang ketika $a d u$ telah dihilangkan, para misionaris menjadi sangehowu.

\footnotetext{
49 BRM, 1875, hal. 311.

50 BRM, 1875, hal. 311.
}

Hal ini menjadi nyata dalam upacara fangasi. Jawaduha mengatakan kepada anak-anaknya, 'walaupun saya akan pergi, jangan sedih dan takut, gurumu, (dia maksudkan Misionaris Kramer) akan menjaga dan memberkatimu.'50 Misionaris menggantikan orang tua, yang dalam tradisi Nias, hadir sesudah kematiannya dalam bentuk $a d u$. Dengan kata lain, misionaris dilihat sebagai pengganti $a d u$ dan ere.

Namun perkembangan sesudah peristiwa ini memperlihatkan bahwa kepercayaan orang pada roh-roh leluhur tetap menjadi masaalah yang serius dalam sejarah zending dan gereja di Nias. Kepercayaan Ono Niha terhadap roh para leluhur tetap kuat, sebab mereka tetap melakukan upacara-upacara adat. Seperti yang dikatakan oleh Lothar Schreiner, keteguhan dan kekuatan tradisi sebagai satu agama nampak jelas dalam pemujaan terhadap leluhur. Dalam relasi antara orang Kristen dan mereka yang sudah meninggal dan para leluhurnya, kepercayaan terhadap mereka merupakan asal usul dan motivasi dari satu tradisi. ${ }^{51}$ Ini adalah dilema yang dihadapi dalam perjumpaan Injil dan adat dalam masa zending. Larangan terhadap tradisi adat akan mempengaruhi ketertarikan suku terhadap Kekristenan. Namun mengijinkannya, berarti membuka kesempatan bagi kepercayaan lama untuk tetap kuat. Hal inilah yang menyebabkan para motivasi memilih sikat tidak bersahabat dengan adat.

Sesudah zending menjadi lebih berhasil, para misionaris menjadi kurang toleran terhadap adat di sekitar kematian. Hal ini mencapai puncaknya ketika mereka melarang unsur-unsur tertentu dari adat yang dianggap bertentangan dengan Kekristenan. Sikap toleran Kramer terhadap adat seperti yang dijelaskan dalam contoh mengenai kematian Jawaduha, berobah di tahun-tahun sesudahnya ketika Kekristenan menjadi lebih kuat. Dia memasuki rumah-rumah keluarga dan membuang adu mereka. Dia juga melarang semua adat yang menurutnya mempunyai hubungan dengan agama asli. Dia mulai menetapkan aturan-aturan dengan tujuan menggantikan adat lama dengan kebiasaan Kristen yang baik. Bila seseorang meninggal, hanya seekor babi dapat disembelih, padahal di waktu lampau setidaknya tiga atau empat ekor.

${ }^{51}$ Lothar Schreiner, Adat Dan Injil: Perjumpaan Adat Dengan Iman Kristen Di Tanah Batak (Jakarta: BPK Gunung Mulia, 2003), 167. 
Di waktu lampau, bila seseorang meninggal ada ratapan dan perkabungan yang luar biasa, kini sesudah menjadi Kristen, orang harus bersikap sebagai orang Kristen yang baik. Mereka harus tenang dan maksimal dapat meneteskan air mata secara diam-diam. ${ }^{52}$ Menurut Kramer, sikap ini sesuai dengan Kekristenan.

Sikap yang tidak toleran terhadap adat pemakaman dapat juga dilihat pada misionaris lain. Misalnya, ketika Ama Mandranga dari pos Dahana meninggal pada hari pertama Pantekosta di tahun 1895, Sundermann mengumumkan bahwa Ama Mandranga adalah seorang yang percaya kepada Yesus Kristus, Tuhan dan Penyelamatnya. Dia telah menolak kekafiran. Karena itu, tradisi adat kafir tidak bisa dilakukan terhadapnya. Segala sesuatu yang berhubungan dengan $a d u$ harus ditiadakan. Satusatunya hal yang diijinkan oleh Sundermann adalah memenuhi permintaan keluarganya untuk meletakkan foto Ama Mandranga di dinding rumahnya. ${ }^{53}$ Sundermann menyetujui hal ini, karena tidak bertentangan dengan tradisi Eropa dan Kekristenan. Ama Mandranga dimakamkan oleh Sundermann yang menggunakan liturgi yang biasa digunakan dalam gereja-gereja di Jerman, yang diterjemahkannya sendiri. Contoh lain adalah ketika Fadoli, Salawa Iraono Huna meninggal. Dia telah menjadi seorang Kristen dan telah memusnahkan semua adu nya. Ketika dia meninggal, tidak dilakukan upacara adat yang semestinya dibuat untuk seorang salawa. Dia dimakamkan dengan satu liturgi Kristen. Sebuah salib diletakkan di atas makamnya, dan dibuat sebuah pesta sederhana. ${ }^{54}$ Juga Afore, seorang salawa dari Hili Hondrö, telah menjadi Kristen dan telah memusnahkan semua $a d u$. Ketika dia jatuh sakit, dan akan meninggal, dia tidak berbalik kepada adu. Misionaris Hippenstiel datang mengunjunginya dan menanyakan apakah dia masih memiliki materi kafir dalam rumahnya. Afore menjawab, tidak, semua sudah dimusnahkan ketika dia masih mengikuti pelajaran katekisasi. Afore meninggal di bulan Oktober 1905. Ketika dia mau meninggal, dia meminta Guru Jemaat Filemo untuk tinggal bersamanya. Dia berdoa dan ketika dia sudah

52 BRM, 1879, hal. 68-69.

53 BRM, 1899, hal. 104.

54 Anonim, Niassische Häuptlinge II, 1912, 15-16.

55 Ibid., 28.

56 BRM, 1900, 327-328. terlalu lemah, Filemo melanjutkannya hingga Afore meninggal. Misionaris sangatlah gembira, karena ketika dia tiba di rumah Afore, tidak ada suara tangisan, walaupun Afore baru saja meninggal. Inilah yang dia maksudkan dengan tradisi Kristen. Afore meninggalkan pesan: 'Dalam keadaan krisis, jangan meminta nasehat dari saudaramu yang masih kafir, mintalah nasehat dari guru jemaat atau misionaris'. ${ }^{55}$ Peristiwa yang sama terjadi juga di Sogae'adu. Seorang mantan ere adalah orang pertama yang dibaptiskan di kampungnya. Misionaris Momeyer menghancurkan semua adunya dan ketika dia meninggal, dia dimakamkan dengan ibadah pemakaman Kristen. ${ }^{56}$

Dari contoh-contoh di atas menjadi nyata bahwa sikap para misionaris terhadap adat pemakaman berobah menjadi kurang toleran dan juga memperlihatkan upaya-upaya mereka untuk menggantikan upacara adat dengan upacara Kristiani atau lebih tepat dengan tradisitradisi Eropa. Sikap ini khususnya nampak di wilayah di mana Kekristenan telah berakar dan berkembang. Kita dapat membandingkan sikap ini dengan sikap para misionaris di Sumba. Sesudah Kekristenan berakar dan berkembang di Sumba, para misionaris mulai dengan tegas melarang unsur-unsur adat yang dilihat tidak Kristiani. Misalnya pemukulan gong ketika seseorang meninggal dengan tujuan memberitahukan berita kematian itu pada orang lain. Pemukulan gong dilarang karena dianggap berhubungan dengan kepercayaan Marapu. ${ }^{57}$ Penerapan disiplin gereja juga mulai dilakukan di Nias sesudah Kekristenan bertumbuh dengan cepat.

Sikap para misionaris terhadap adat di sekitar kematian sama saja dengan sikap mereka terhadap tradisi adat yang lain. Sesudah Kekristenan menjadi cukup 'berkuasa' di Nias, para misionaris mulai mengeluarkan larangan mengenai adat yang mereka golongkan sebagai 'hukum-hukum lama' Salah satu unsur dalam tradisi pemakaman yang tidak disukai oleh para misionaris karena hubungannya yang erat dengan agama lama, adalah fangasi (pengadaan pesta sesudah pemakaman). Menurut para

57 F.D. Wellem, Injil Dan Marapu Suatu Studi Historis-Teologis Tentang Perjumpaan Injil Dengan Masyarakat Sumba Pada Periode 1876-1990 (Jakarta: BPK Gunung Mulia, 2004), 341. 
misionaris, tradisi fangasi mengandung bahaya bagi orang Kristen Nias, karena mereka dapat saja dipengaruhi untuk kembali pada kepercayaan kepada roh-roh para leluhur. Biaya bagi fangasi sebenarnya cukup tinggi dan dapat menyulitkan anggota keluarga yang ditinggalkan. Karena alasan inilah di tahun 1917, melalui satu konperensi Satua Niha Keriso, satu peraturan dikeluarkan untuk melarang fangasi. 58

Agar peraturan ini benar-benar dituruti, maka mereka yang menghadiri konperensi diminta untuk menjadi contoh. Para Satua Niha Keriso yang mempraktekkan fangasi dipecat dari posisi mereka. Kemudian ada usul, agar semua jemaat memiliki pekuburan Kristen dan bila perlu mempekerjakan pengawal untuk menjaganya. Usul ini dipengaruhi oleh tradisi yang ada di Eropa.

Larangan untuk melakukan fangasi disusuli dengan ajaran dari misionaris yang disebar-luaskan oleh para guru jemaat dan pendeta pribumi, juga diterbitkan dalam majalah gereja Toeria. Judul yang diberikan adalah 'tradisi kafir di sekitar kematian'. Para guru jemaat dan pendeta pribumi menerangkan tentang kebiasaan dalam adat yang dilaksanakan sebelum kematian (fangotome'ö) dan ketika seseorang meninggal (fangai eheha bagi seorang bangsawan), juga upacara waktu pemakaman (fangasi) dan empat hari sesudah pemakaman (fanibo tufo dan fangai mökömökö). Semua kegiatan ini dianggap ‘hukum lama' yang harus ditinggalkan karena tidak sesuai dengan ajaran Kristiani. Semua upacara ini dapat diganti dengan ibadah Kristen. ${ }^{59}$

Orang Kristen Nias sering mempertanyakan kebangkitan orang yang sudah meninggal juga. Karena itu maka Guru Jemaat Filemo dan Guru Jemaat Talini menulis sebuah artikel tentang kebangkitan orang mati yang diterbitkan dalam majalah Toeria. ${ }^{60}$ Dalam tulisan mereka, tiga hal ditekankan yaitu:

- Kebangkitan: Orang Kristen tidak harus takut terhadap kematian, karena ada kebangkitan. Kuasa kebangkitan Yesus Kristus membangkitkan orang-orang yang percaya (Rom 8:1; Phil 3:21; 1 Kor 15:25), sebab Kristus adalah pemilik kehidupan yang memanggil

58 Toeria, 4/12 (1917). Aturan lain menyangkut larangan famoto (sunat) dan fangöhözi (perataan gigi) bagi semua orang Kristen. orang mati ke dalam satu kehidupan kekal (Yoh 5:21).

- Kebangkitan tubuh: yang dimaksudkan dengan kebangkitan tubuh adalah kebangkitan tubuh yang baru, tubuh yang sempurna, yang tidak cacat. Tubuh yang baru tidak akan mati (1 Kor 15:42, 49; Luk 20:35), tubuh itu memiliki kekuatan dan kehormatan, itu adalah tubuh roh, sama seperti Yesus Kristus ketika Dia memperliharkan diriNya kepada para murid sesudah kebangkitanNya. Orang-orang yang tidak percaya, juga akan dibangkitkan, tapi mereka akan menerima tubuh yang tidak memiliki kekuatan dan kehormatan (Dan 12:2). Kelakuan seseorang selama hidupnya akan terlihat pada saat kebangkitan.

- Zaman akhir. Mereka menerangkan bahwa Yesus berjanji akan kembali lagi. (Yoh 3:3), tapi tak seorangpun tahu kapan waktunya (Mk 13:32). Alkitab memuat tulisan tentang tanda-tanda kedatangan Kristus seperti misalnya dalam Mat. 24:29-31, Luk 21:9, 2 Thes. 2:3, dan Wahyu 20-22. Akhirnya dua orang guru jemaat itu menulis: 'Karena itu saudara-saudaku, tetaplah teguh, tidak goyah, senantiasa bersukacita dalam pekerjaan Tuhan, karena ketahuilah, di dalam Tuhan, upayamu tidak sia-sia' (1 Kor 15:58). Tulisan tentang kebangkitan ini adalah hasil ajaran para misionaris di seminari, yang telah menjadi penghiburan yang besar bagi anggota-anggota jemaat.

\section{Reaksi Ono Niha atas Pelarangan dari Misionaris}

Walaupun tanpa adu and ere, Ono Niha tetap melakukan upacara adat di sekitar kematian, seperti misalnya fangotome'ö (memberi makan seseorang yang akan meninggal), fange'esi (menangisi orang yang meninggal), fangasi (pengadaan pesta sesudah pemakaman), dan fanibo tufo (meletakkan kasur dan pakaian di atas makam). Satu-satunya hal yang ditinggalkan ialah fangai mökömökö yang berhubungan dengan pembuatan $a d u$. Ritus-ritus lain masih tetap dilakukan. Seperti yang dikatakan sebelumnya, peran dari ere dan $a d u$ diambil alih oleh pelayan

59 Toeria, 8/1 (1921), hal. 3-4; Toeria, 10/6-7 (1923); Toeria, 11/6 (1924); Toeria, 11/7-8 (1924), hal. 25-26, 30 .

${ }^{60}$ Toeria, 6/2 (1919). 
gereja yang memimpin doa dan ibadah. Walaupun sudah ada larangan yang diputuskan oleh konferensi para satua Niha Keriso, sangatlah sulit bagi Ono Niha untuk meninggalkan ritus adat mereka di sekitar kematian, khususnya fangasi. Inilah alasan mengapa para misionaris, didukung oleh para guru jemaat dan pendeta pribumi menetapkan seperangkat disiplin gereja (amakhoita). Dalam amakhoita pertama tahun 1923, ada dua aturan mengenai upacara adat di sekitar kematian yaitu: pertama, bila seseorang meninggal, harus dilaporkan kepada pelayan gereja. Bila tidak, mereka yang melalaikan hal ini harus menerima bimbingan khusus selama tiga bulan. Kedua, Fangasi dan fangai mökömökö dilarang. Mereka yang tidak menaatinya akan dikucilkan dari gereja:61 Sikap ini dilanjutkan oleh gereja ketika menjadi satu lembaga di tahun 1936.

Di dalam amakhoita62 secara tegas dikatakan bahwa Orang Kristen tidak diijinkan menyembah roh para leluhur; fangasi dan fanibo tufo dilarang. Orang Kristen juga dilarang menghadiri upacara adat dari orang-orang yang bukan Kristen. Mereka yang melanggar amakhoita akan dihukum dalam bentuk tidak diijinkan menerima sakramen, dan kemungkinan dikeluarkan dari gereja.

Di Pulau-pulau Batu sikap para misionaris NLG tidak berbeda dengan sikap para misionaris RMG di Nias. Mereka dengan tegas melarang pembuatan $a d u$ dan penyembahan roh-roh leluhur. Menangis dengan suara nyaring tidak diijinkan dalam ibadah pemakaman. Para misionaris memperkenalkan pekuburan Kristen di tahun 1931 dan menyetujui acara pembersihan makam di hari Paskah. Orang Kristen dianjurkan melakukan hal ini sebagai peringatan akan kehidupan kekal, walaupun mereka tidak diijinkan membawa persembahan kepada mereka yang sudah meninggal. Siapa yang melanggar ini tidak akan menerima pemakaman Kristiani bila meninggal.63 Yang menarik dari Pulau-pulau Batu adalah, keluarga dari seseorang yang meninggal akan menerima bantuan dari gereja. Bila seorang dewasa meninggal, keluarganya menerima 5 gulden, dan

61 Bnd. Amakhoita Sogoena ba Mbanoea Niha Keriso ba Dano Nias, 1923, 6-8.

62 Bnd. Amakhoita ba mbanoea Niha Keriso si Faoedoe ba Daroma Li Lowalangi, Nihonogöi mbanua Niha Keriso Protestan ba Danö Nias (Ibr. 9:1), 1939. dua setengah gulden bila seorang anak meninggal. Di samping itu, kolekte khusus juga dikumpulkan di setiap jemaat. ${ }^{64}$ Kebijakan yang dimulai oleh Misionaris Schröder ini bertujuan menolong keluarga dalam kebutuhan mereka dan untuk mendorong kesatuan jemaat-jemaat. Juga ada upaya yang dilakukan untuk mendorong anggota jemaat agar mengambil bahagian dalam membiayai pelayanan gereja. Bantuan yang diberikan di saat kematian seseorang, dihubungkan dengan tanggungjawab yang ditentukan oleh setiap jemaat.

Sekali lagi, fangasi, fanibo tufo dan unsurunsur lain dari adat dilarang dalam amakhoita. Orang-orang Kristen merasa sulit sekali untuk menaati hukum-hukum ini, sehingga banyak orang yang dikucilkan dari gereja. Fakta ini menghasilkan satu kesepakatan yang dibuat dalam sidang sinode kedua di tahun 1937. Dalam sinode ini mereka meninjau ulang dan membahas tradisi adat dalam hubungannya dengan Kekristenan. Tugas ini dilakukan oleh tiga kelompok kerja secara bersama yaitu pemimpin adat, para pendeta dan delegasi dari pemerintah kolonial Belanda. Pemimpin adat yang dipilih adalah Ama Wirö, Josefo, Adolf, Ama Wele, Tuhe'ö, Faonaso, dan Waöndrö. Hasil kerja mereka diserahkan kepada para misionaris untuk dibicarakan dalam pertemuan pendeta di bulan April 1938 dan kemudian dalam pertemuan badan pekerja harian sinode. ${ }^{65}$ Hasil dari diskusi-diskusi itu tidak digunakan dengan baik sebelum permulaan Perang Dunia II.

Sesudah Perang Dunia II, sekali lagi BNKP dihadapkan dengan upacara adat di seputar kematian. Masaalahnya Ono Niha tetap mempraktekkan fangasi dan fanibo tufo, walaupun sudah dilarang di jaman zending. Masalah itu dididskusikan lagi dalam sidang sinode BNKP tahun 1960. Ada utusan yang menentang unsur-unsur adat yaitu fangasi dan fanibo tufo. Mereka adalah utusan dari daerahdaerah pedalaman. Mereka disokong oleh para

63 "Amachoita Niha Sarani ba Hoelo Batoe: Nihonogöi ba Gorahua Sebua, 29 Desember 1931," dalam Toeria Hoelo Batoe, 4/5 (1932).

${ }^{64}$ Toeria Hoelo Batoe, 4/2 (1932)

${ }^{65}$ Toeria, 25/1 (1938). 
misionaris RMG.6667 Namun larangan fangasi dan fanibo tufo sangat ditentang oleh utusan dari Gunungsitoli. Menurut Jürgen Kosack, latar belakang pendapat utusan dari Gunungsitoli adalah pengaruh nasionalisme Waktu itu di Indonesia dilakukan upaya mendidik rakyat mengenai pentingnya nilai-nilai kebudayaan yang berdasarkan Pancasila. ${ }^{68}$ Delegasi dari Gunungsitoli yang pada umumnya telah mendapat pendidikan cukup tinggi berpendapat bahwa, setiap bangsa mestinya mengawetkan tradisinya untuk memperkaya kebudayaan bangsa. Untuk menjamin bahwa orang Kristen tidak akan kembali mempraktekkan agama lama, tradisi adat ini harus diterangi oleh Firman Allah. Salah satu ukuran yang dipastikan di Gunungsitoli adalah bahwa istilah fangasi diganti dengan istilah fame'e ö zohalöwö (memberi makan para pekerja) dan istilah fanibo tufo menjadi fananö bunga (penanaman bunga). Waktu untuk melakukan fame'e ö zohalöwö dipindahkan dari sesudah pemakaman ke waktu fananö bunga. ${ }^{69}$

Perbedaan pendapat yang terjadi dalam sidang sinode tahun 1960 tidak dapat diatasi, karena tidak ada keöompok yang bersedia berkompromi. Jadi percakapan tentang ini ditunda ke tahun kemudian. Dalam sidang sinode tahun 1961, pemimpin sinode menyebut dalam laporan mereka bahwa tradisi adat di seputar kematian, termasuk semua praktek menyembah roh orang mati dan berdoa kepada roh leluhur, tidaklah sejalan dengan iman Kristen. Adalah bertentangan dengan iman Kristen untuk meletakkan barang-barang orang yang sudah meninggal di dalam kuburannya, juga untuk memberi makan roh orang yang sudah meninggal di dalam maupun di luar rumah. Memberi makan kepada para (famée ö zohalöwö) juga tidak sejalan dengan iman Kristen, sebab sebenarnya yang dilakukan adalah merayakan dan menghormati orang yang sudah meninggal, apalagi karena hal itu dilakukan

${ }^{66}$ J. Kosack, Wawancara, Wuppertal, 8 Juni 2002.

67 Soekarno, Dari Proklamasi Sampai Takari (Jakarta: Prapantja, 1965), 484-621.

${ }^{68}$ J. Kosack, Wawancara, Wuppertal, 8 Juni 2002.

${ }^{69}$ Ama Watörö Lase, "Waöwaö Wa'aniha Keriso Ba Danö Niha (Nias) Barö Zi Otu Fache Wa'ara, Wanuriaigö Turia Somuso Dödö,” in Waöwaö Duria Somuso Dödö Ba Danö Niha, ed. F.D. Harefa and R. Heering, 1971, 67. pada hari keempat.70 Keputusan itu tidak diterima oleh beberapa orang utusan, khususnya mereka yang berasal dari Gunungsitoli. Karena itu pimpinan sinode membiarkan masaalah ini mengambang dan membuka kesempatan untuk melakukan semua upaya untuk mendiskusikan tema ini.

Sesudah bergumul dengan masaalah ini beberapa waktu lamanya, maka dalam sidang sinode tahun 1965 diambil keputusan tentang dua hal: 1. Dinyatakan bahwa adalah bertentangan dengan Iman Kristen untuk menyembah roh para leluhur, karena itu, anggota BNKP dilarang untuk melakukan ritusritus yang bertujuan menyembah roh para leluhur, seperti misalnya wame'e ba zi no mate ngawalö gamagamara (memberi barang-barang kepada orang yang sudah meninggal), wangaröfi li töi mbekhu zi no mate (berdoa kepada roh para leluhur) atau fame'e gö mbekhu zi no mate (memberi makan roh orang yang sudah meninggal). 2. Adalah baik untuk menanam bunga di makam, sejauh hal ini tidak dilakukan pada dan dihubungkan dengan hari keempat, sehingga orang Kristen tidak kembali lagi ke kepercayaan lama.7172 Dengan pernyataan ini, orang dapat saja melakukan ritus fananö bunga. ${ }^{73}$ Di kemudian hari, pernyataan ini diganti dengan 'doa syukur dan doa syafaat' sebab Allah telah menolong keluarga melewati acara pemakaman dan Allah diminta untuk tetap menjaga keluarga yang ditinggalkan.

\section{KONKLUSI}

Dalam seluruh proses perjumpaan Kekristenan dengan adat di seputar kematian, dapat dilihat bahwa Ono Niha tetap bertekad melakukan tradisi dan adat mereka yang diturunkan dari generasi ke generasi. Walaupun mereka mengalami adanya perobahan dalam pemegang peran, lambang-lambang dan istilahistilah yang digunakan, namun jiwa dari upacara ini tetap hidup. Amakhoita tidak berhasil

70 Laporan Pengurus Besar pada Persidangan Sinode tahun 1961.

${ }^{71}$ Keputusan Sinode ke-27 BNKP di Ombölata, 29 April 1965.

72 W Gulo, Benih Yang Tumbuh XIII: Banua Niha Keriso Protestan (Semarang: Persetakan Satya Wacana, 1983), 207.

${ }^{73}$ Lase, "Waöwaö Wa'aniha Keriso Ba Danö Niha (Nias) Barö Zi Otu Fache Wa'ara, Wanuriaigö Turia Somuso Dödö." 
menghilangkan adat, walaupun $a d u$ berhasil dihilangkan. Hal ini tetap hidup dalam kehidupan sesehari Ono Niha hingga hari ini. Masih terdapat Ono Niha yang percaya dan menyembah roh leluhur mereka, masih terdapat yang mempercayai bahwa arwah nenek moyang merupakan sumber berkat bagi keturunannya, dan sumber kutuk apabila tidak mengikuti pesanannya pada waktu hidup. Hal ini memang tidak hanya terjadi di Nias. Suh Sung Min $^{74}$ melakukan penelitian di daerah-daerah Minahasa, Sumba, Batak dan Korea. Hasil penelitiannya memperlihatkan bahwa hingga hari ini, walaupun daerah-daerah ini telah menerima Injil, penyembahan leluhur masih tetap berlanjut. Karena itulah Suh Sung Min mengusulkan agar gereja-gereja melakukan upaya kontekstualisasi secara sungguh. Bagaimana sikap gereja? Sejak zaman Zending sangat tegas sikap menolak kebudayaan dan terutama agama asli, dan selanjutnya dalam bentuk larangan dan siasat dimuat dalam Siasat Gereja atau yang kemudian dikenal dengan nama Tertib Penggembalaan.

Namun, penting dipahami bahwa walaupun sejak misionaris menolak sistem kepercayaan Ono Niha, tetapi masih saja ada yang mempercayainya. Oleh karenanya, penting menggumuli pendekatan baru, dalam usaha kontekstualisasi Injil di Nias.

\section{REFERENSI}

Danandjaja, James. Ono Niha: Penduduk Pulau Nias, 1976.

Dong, Kim Ki. Roh, Jiwa Dan Tubuh. Tangerang: Barea indonesia, 2003.

Gulo, W. Benih Yang Tumbuh XIII: Banua Niha Keriso Protestan. Semarang: Persetakan Satya Wacana, 1983.

- - - , ed. "Injil Dan Budaya Nias." In Seminar Lokakarya Perjumpaan Injil Dan Budaya Nias Di Gunungsitoli Nias. Gunungsitoli: Panitia Semiloka, 2004.

Hadiwijono, Harun. Religi Suku Murba Di Indonesia. BPK Gunung Mulia, 2000.

Hämmerle, Johannes M. Lawaendröna - Si Pencari Kehidupan Abadi Hingga Ke Bulan. Gunungsitoli: Museum Pusaka Nias, 2013.

${ }^{74}$ Sung Min Suh, Injil Dan Penyembahan Nenek Moyang: Suatu Studi Perbandingan AntropologisMisiologis Tentang Penyembahan Nenek Moyang Di
Harefa, Faogoli. Hikayat Dan Cerita Bangsa Serta Adat Nias. Sibolga: Rapatfonds Residentie Tapanoeli, 1939.

Harita, Sarofanotona. “Gerakan Pertobatan Masal Sebagai Hasil Pertemuan Gerakan Pietisme Dengan Nilai-Nilai Budaya Agama Suku Nias." Sekolah Tinggi Teologi Jakarta, 1990.

Laiya, Bamböwö. Solidaritas Kekeluargaan Dalam Salah Satu Masyarakat Desa Di Nias, Indonesia. Yogyakarta: Gadjah Mada University Press, 1980.

Lase, Ama Watörö. “Waöwaö Wa'aniha Keriso Ba Danö Niha (Nias) Barö Zi Otu Fache Wa'ara, Wanuriaigö Turia Somuso Dödö." In Waöwä̈ Duria Somuso Dödö Ba Danö Niha, edited by F.D. Harefa and R. Heering, 1971.

Schreiner, Lothar. Adat Dan Injil: Perjumpaan Adat Dengan Iman Kristen Di Tanah Batak. Jakarta: BPK Gunung Mulia, 2003.

Schröder, E.E.W.G. Nias: Ethnographische. N. v. bockhandel en drukkerij voorheen E. J. Brill, 1917.

Soekarno. Dari Proklamasi Sampai Takari. Jakarta: Prapantja, 1965.

Suh, Sung Min. Injil Dan Penyembahan Nenek Moyang: Suatu Studi Perbandingan Antropologis-Misiologis Tentang Penyembahan Nenek Moyang Di Indonesia (Minahasa, Sumba, Dan Batak) Dan Di Korea. 1st ed. Media Pressindo, 2001.

Sundermann, Heinrich. Die Insel Nias Und Die Mission Daselbst: (Mit Anhang, "Niassische Literatur") : Eine Monographie. Barmen: Verlag des Missionhauses, 1905.

- - . "Die Psychologie Des Niassen." In Allgemeine Mission Zeitschrft, edited by Johannes Gustav Warneck. 14th ed. Gütersloh: Bertelsmann, 1887.

Suzuki, Peter. The Religious System and Culture of Nias, Indonesia. Washington: 'S Gravenhage., 1959.

Swellengrebel, J. L., Sonia Hummel-Parera, Th. van den End, A. Hadiwiyata, and Lembaga Alkitab Indonesia. Mengikuti Jejak Leijdecker : Satu Setengah Abad Penerjemahan Alkitab Dan Penelitian Bahasa Dalam Bahasa-Bahasa Nusantara. Jakarta: Lembaga Alkitab Indonesia, 2006.

Thomas, J.W. "No Title." Berichte der Rheinische Missions-Gesellschaft (n.d.): 13-15.

Wagner, Richard. Die Mission Auf Nias. Barmen: Missionshaus, 1915.

Indonesia (Minahasa, Sumba, Dan Batak) Dan Di Korea, 1st ed. (Media Pressindo, 2001), 275-317. 
Wellem, F.D. Injil Dan Marapu Suatu Studi HistorisTeologis Tentang Perjumpaan Injil Dengan Masyarakat Sumba Pada Periode 1876-1990. Jakarta: BPK Gunung Mulia, 2004.

Zaluchu, Sonny E. “Lowalangi: From the Name of an Ethnic Religious Figure to the Name of God." HTS Teologiese Studies / Theological Studies 77, no. 4 (April 20, 2021). http://www.hts.org.za/index.php/HTS/arti cle/view/6390.

Zebua, S. Sejarah Kebudayaan Ono Niha. Seri 2., n.d. 